\title{
Precedent set as NIH loses court battle
}

\section{Washington}

IN a decision that threatens a host of prominent scientific misconduct investigations, a federal judge has ruled that the Public Health Service's existing mechanisms for policing research are illegally constituted and so are invalid.

Although, by early this week, federal officials had not yet announced their response, the ruling appears to set a precedent that could halt all 60 -odd misconduct investigations now under way at the National Institutes of Health (NIH).

The decision, by Wisconsin district judge Barbara Crabb, is on a portion of the closely watched case of University of Wisconsin researcher James Abbs, who has been under investigation since 1987 by the NIH for allegedly fabricating data. (Certain curves in an Abbs Neurology paper are alleged to have been traced from one of his previous papers on different patients.)

Abbs claims that the protracted investigation has violated his 'due-process' rights, which include the right to crossexamine witnesses, to examine evidence and to be informed of all charges. Abbs also claims that the misconduct procedures of the Public Health Service (of which NIH are a part) had been illegally implemented without the public comment and review period required of federal regulations.

Although the judge decided that Abbs did not have the legal basis to sue for dueprocess protection (among other things, he could not convincingly show that the investigation had prevented him from continuing his work), she was certainly no more sympathetic towards the government.

"The Public Health Service is not exempt from the requirements of the Administrative Procedures Act. It is required to promulgate agency rules according to the Act's provisions, which include publishing notice of any proposed rules in order to invite comment from those persons who are likely to be regulated by the rules the agency seeks to adopt", the judge wrote in her 28 December decision.

Until the Public Health Service releases its' regulations for public comment and review (a process that can take from months to years), they are "invalid", Judge Crabb ruled. Although the decision only makes the NIH illegal in Wisconsin's Western District, it sets a strong legal precedent that can be used as the basis of a dismissal suit by any other non-government researcher currently subject to an NIH probe. (Government employees under investigation, like embattled AIDS researcher Robert Gallo, are not entitled

to the same protection.)

"Unless NIH acquiesces nationally, you will see a torrent of lawsuits," says attorney Robert Charrow of the Washington law firm Crowell and Moring. Assuming that NIH concedes that its rules are illegal and will probably be found invalid whenever they are challenged, the agency will probably have to choose between two unpleasant options, Charrow says. NIH can either offer researchers currently under investigation a one-totwo-year wait while the agency proposes new regulations and has them approved, or offer to convert their cases immediately into formal department proceeding, where full due process rights are already in place. Although the latter ensures prompt court-like treatment, researchers CONFLICT OF INTEREST

\section{Then there were four}

\section{Washington}

US health officials have revealed that yet another colleague of AIDS researcher Robert Gallo is under investigation, bringing the total to four inquiries in the past year at Gallo's laboratory.

In a confidential letter released last week by congressional investigators, the National Cancer Institute (NCI) reported that Prem Sarin, now second-in-command at the laboratory, has been removed from his position and is facing suspension for possible conflict-of-interest violations.

NCI officials are focusing on the possibility that in 1987 Sarin took money from two drug companies, one of which made an anti-AIDS drug that was being tested at the laboratory. "Based on the very serious nature of the possible violations, on 21 December, [Sarin] was removed from his position as Deputy Chief, Laboratory of Tumor Cell Biology, and reassigned to a non-supervisory, nonmanagerial position", the NCI letter states.

Sarin has also been given two weeks to respond to a proposal to suspend him from all duties without pay until the outcome of an NCI investigation. His lawyer has denied the allegations of wrongdoing and promised full cooperation.

The NCI decision comes in the wake of a six-month investigation by the staff of congressional watchdog Representative John Dingell (Democrat, Michigan). Sarin had been one of the witnesses at a hearing Dingell called last year to review the actions of another Gallo associate, Syed Salahuddin, who was later convicted of steering NCI funds to a business of which he was a part-owner. found guilty in such a proceeding can be barred for life from obtaining government grants without an opportunity for further appeal. Such a proceeding normally only comes after a full NIH investigation has found evidence of misconduct.

Officials at the NIH Office of Scientific Integrity (OSI), which handles misconduct investigations for the agency, were not available for comment.

OSI has been under increasing fire for its lack of due process protections (see Nature 346 9; 1990), and NIH officials have privately worried that the entire misconduct process is vulnerable to legal challenge, a fear that now appears to have been borne out with the first courtroom test of the system. Should NIH be forced to halt all current activities and start again, scientists now under investigation can expect at least another year in limbo while NIH scramble to rebuild their misconduct machine.

Christopher Anderson
Although Sarin had not expected to be a target of that inquiry, Dingell launched a surprise attack at the hearing by questioning him at length about his representation of a Wisconsin company at a 1986 Food and Drug Administration meeting (see Nature 345, 99; 1990).

Since then, Dingell's staff have subpoenaed Sarin's personal bank records, $\mathrm{NCI}$ files and financial information from the two drug companies in an attempt to document their suspicions of illegal conflicts of interest. It was in response to one such request that $\mathrm{NCI}$ officials reviewed the records themselves and decided to remove Sarin from his post.

Beyond the laboratory connection, there is apparently no link between the Sarin and Salahuddin investigations, or with the continuing investigations of Gallo and his former chief virologist Mikulas Popovic for possible misconduct related to the discovery of the AIDS vaccine.

Salahuddin was last year found guilty and sentenced to repay $\$ 12,000$ and carry out 1,750 hours of research as a community service. While the Gallo and Popovic investigations are still months away from any conclusion, Dingell continues to show his interest in the case by investigating others of Gallo's colleagues.

Whether the high number of questionable dealings that the Dingell staff has uncovered reflects a chance cluster of wrongdoing, an unusually low ethical standard in Gallo's laboratory or a fundamental clash between common scientific practice and federal regulations will no doubt be on the agenda of one of several hearings expected this year.

Christopher Anderson 